"Analyzing the FDI dynamics and the investment climate impacting the economic development of BSEC"

\begin{tabular}{|c|c|}
\hline AUTHORS & $\begin{array}{l}\text { Evangelos Siskos (D https://orcid.org/0000-0002-5221-4444 } \\
\text { Konstantia Darvidou iD https://orcid.org/0000-0002-8113-7302 }\end{array}$ \\
\hline ARTICLE INFO & $\begin{array}{l}\text { Evangelos Siskos and Konstantia Darvidou (2020). Analyzing the FDI dynamics } \\
\text { and the investment climate impacting the economic development of BSEC. } \\
\text { Economics of Development, 19(3), 32-43. doi:10.21511/ed.19(3).2020.04 }\end{array}$ \\
\hline DOI & http://dx.doi.org/10.21511/ed.19(3).2020.04 \\
\hline RELEASED ON & Tuesday, 01 December 2020 \\
\hline RECEIVED ON & Monday, 27 July 2020 \\
\hline \multirow[t]{2}{*}{ ACCEPTED ON } & Friday, 28 August 2020 \\
\hline & $(c))$ EY \\
\hline LICENSE & $\begin{array}{l}\text { This work is licensed under a Creative Commons Attribution } 4.0 \text { International } \\
\text { License }\end{array}$ \\
\hline JOURNAL & "Economics of Development" \\
\hline ISSN PRINT & $1683-1942$ \\
\hline ISSN ONLINE & $2304-6155$ \\
\hline PUBLISHER & LLC "Consulting Publishing Company "Business Perspectives" \\
\hline FOUNDER & Simon Kuznets Kharkiv National University of Economics \\
\hline & ニニ:- \\
\hline NUMBER OF REFERENCES & NUMBER OF FIGURES \\
\hline 22 & 0 \\
\hline
\end{tabular}

(C) The author(s) 2021. This publication is an open access article. 


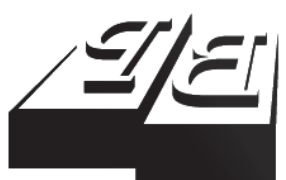

BUSINESS PERSPECTIVES

Publisher

LLC "CPC "Business Perspectives"

Hryhorii Skovoroda lane, 10,

Sumy, 40022, Ukraine

www.businessperspectives.org

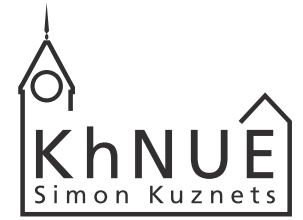

\section{S. KUZNETS KHNUE}

\section{Founder}

Simon Kuznets Kharkiv National University of Economics, Nauky avenue, 9-A, Kharkiv, 61166,

Ukraine

http://www.hneu.edu.ua/

Received on: 27th of July, 2020 Accepted on: 28th of August, 2020 Published on: 1st of December, 2020

(C) Evangelos Siskos,

Konstantia Darvidou, 2020

Evangelos Siskos, Doctor of Science (Economics), Professor of International Economic Relations, Department of International and European Economic Studies (Kozani), University of Western Macedonia, Greece.

Konstantia Darvidou, Ph.D. in International Economic Relations, University of Western Macedonia, Greece.

\section{(c) (i)}

This is an Open Access article distributed under the terms of the Creative Commons Attribution 4.0 International license, which permits unrestricted re-use, distribution, and reproduction in any medium, provided the original work is properly cited.

\title{
ANALYZING THE FDI DYNAMICS AND THE INVESTMENT CLIMATE IMPACTING THE ECONOMIC DEVELOPMENT OF BSEC
}

\begin{abstract}
The paper concentrates on the analysis of inward and outward FDI in the BSEC countries, their structuring by countries of origin and destination, and how the investment climate (in particular economic freedom and economic development) affects the actual FDI influx in the region. The BSEC countries became considerably attractive for FDI at the beginning of the 2000s, and now they receive about $4 \%$ of the world FDI. All the BSEC countries are net recipients of FDI, but some of them also actively invest abroad. Most FDI to the region originates in Europe. FDI is the most important for several small BSEC economies, especially in some periods when they made a significant contribution to capital formation. Despite a temporary increase in imports, FDI also helped to stabilize the balance of payments. Most BSEC countries usually outperform average countries worldwide by trade freedom, low tax burden, fiscal health, financial freedom, property rights, and low inflation. However, this group of countries is quite diverse by particular indicators. Corruption and excessive regulations often act as the drawbacks for the investment climate. The overall economic freedom and low tax burden are the strongest determinants of inward FDI to the BSEC countries. Improving the overall economic freedom, protecting property rights, and better control over government spending are the most crucial for stimulating economic growth. Economic growth and trade freedom are less important factors for FDI.
\end{abstract}

Keywords

JEL Classification foreign direct investments, investment climate, Black Sea Economic Cooperation

F21, F23, P44, P45

Евангелос Сіскос (Греція), Констанція Дарвіду (Греція)

\section{АНАЛІЗ ДИНАМІКИ ПРЯМИХ ІНОЗЕМ- НИХ ІНВЕСТИЦІЙ ТА ІНВЕСТИЦІЙНОГО КЛІМАТУ, ЩО ВПЛИВАЕ НА ЕКОНОМІЧ- НИЙ РОЗВИТОК ЧЕС}

\section{Анотація}

Стаття зосереджена на аналізі внутрішніх та зовнішніх ПІІ в країнах ОЧЕС, їх структурування за країнами походження та призначення, а також як інвестиційний клімат (зокрема економічна свобода та економічний розвиток) впливає на фактичний приплив ПІІ в регіоні. Країни ОЧЕС стали значно привабливими для ПІІ на початку 2000-х років, і зараз вони отримують близько 4\% світових ПІІ. Усі країни ОЧЕС $є$ чистими одержувачами ПІІ, але деякі з них також активно інвестують за кордон. Більшість ПІІ в регіоні бере свій початок в Європі. ПII $є$ найважливішими для декількох малих економік ОЧЕС, особливо в деякі періоди, коли вони зробили значний внесок у формування капіталу. Незважаючи на тимчасове збільшення імпорту, ПІІ також допомогли стабілізувати платіжний баланс. Більшість країн ОЧЕС зазвичай перевершують середні країни у світі за свободою торгівлі, низьким податковим навантаженням, фіскальним здоров'ям, фінансовою свободою, правами власності та низькою інфляцією. Однак, ця група країн досить різноманітна за певними показниками. Корупція та надмірне регулювання часто виступають недоліками для інвестиційного клімату. Загальна економічна свобода та низьке податкове навантаження $є$ найсильнішими факторами, що впливають на прямі ПІІ до країн ОЧЕС. Поліпшення загальної економічної свободи, захист прав власності та кращий контроль за державними витратами $€$ найважливішими для стимулювання економічного зростання. Економічне зростання та свобода торгівлі $є$ менш важливими факторами для ПІІ.

Ключові слова

Класифікація JEL прямі іноземні інвестиції, інвестиційний клімат, Чорноморське економічне співробітництво

F21, F23, P44, P45 


\section{INTRODUCTION}

BSEC (the Black Sea Economic Cooperation) unites countries of various development levels, with cross-membership in other blocs, net FDI recipient countries, and countries that are both active recipients and exporters of investments. The organization consists of both countries located at the Black Sea shore and other neighboring states interested in cooperation within a wider Black Sea area. Some investment projects are of mutual geopolitical interest, but competition between the member states also exists. Despite the existence of intra-bloc FDI, most foreign investment comes from the outside, but still mainly from Europe.

The research on FDI in the BSEC countries mainly concentrates on trends, determinants, and effects of FDI, but usually, the analyzed countries fall into different groups in another way. And selecting the analyzed period may also influence the results.

This paper is devoted to the analysis of inward and outward FDI in the BSEC countries. It studies their structure by origin and destination, the importance for the economy, capital formation and balance of payments, and how the investment climate (in particular economic freedom and economic development) affects the actual influx of FDI in the region.

\section{LITERATURE REVIEW}

Most works related to BSEC dealt with the overall political and economic and political cooperation or trade issues. Few papers considered investment trends in the entire regional bloc. More studies analyzed FDI in BSEC indirectly: either by addressing individual member states or similar groups of countries consisting partially of the BSEC states (the CIS, Southeast Europe, etc.).

Handjiski (2009) said that Southeast Europe had lower investment rates and FDI than the new member states of the EU representing Central Europe and that the investments had started to increase only in the previous few years there. There were structural disproportions in investment in favor of construction instead of machinery and equipment, and only a quarter of investments flowed into the tradable sectors. Most FDI covered privatization and the purchase of existing assets. And a large portion of FDI came from neighboring countries or European companies. Troyan (2012) noted that the BSEC countries have low investment flows among themselves, which are considerably less than the investments among the EU countries.

Papazoglou and Liargovas (1997) explained that the results in attracting foreign capital to the BSEC countries depended on proper timing and forms of privatization, progress in liberalization, market size, trade links, and labor costs. Christie (2003) used a gravity model to find out that FDI in Southeast European countries was lower than expected, even accounting for GDP and geographical distances from Western countries. The reason was worse economic freedom when compared to Central Europe.

Glinavos (2005) studied 6 Black Sea countries (Russia, Ukraine, Georgia, Turkey, Romania, and Bulgaria) to conclude that they lacked foreign investments apparently because of the failed enforcement of the legislative framework than due to the drawbacks of the legislation itself. At that time, the region suffered from an underdeveloped banking system and communications networks, imperfect taxation and privatization schemes, crime, poor enforcement for intellectual property rights, complex certification procedures, and a weak legal system. Nevertheless, many countries primarily tried to raise foreign investments by various incentives and establishing a specialized government agency. Turkey and Bulgaria were more attractive for investments at that time than other considered countries.

Botrić and Škuflić (2006) noted the dependence of inward FDI in Southeast Europe on the completion of the privatization process, trade regime, and infrastructure density. Salavrakos (2006) pointed at the fact that the Eastern Europe and Black Sea region did not originally have strong economic links with the developed economies, which later resulted in lower FDI inflows than those in Central Europe. Also, former links to Greek and Turkish 
capital were re-established in some countries of the region. Vlahinic-Dizdarevic and Blažic (2006) explained specific trends in FDI in Southeast Europe by privatization and tax incentives besides traditional determinants such as market size, market growth, economic development level, and institutional development progress. Astrov and Havlik (2008) noted that the improvement of investment climate would require the settlement of existing frozen conflicts and better political stability in some BSEC countries. Stoian and Filippaios (2008) showed that Greek outward investments were mostly directed to similar countries with a small market, open economies, the rule of law, and a high quality of governance.

Anagnostis (2011) summarized the main determinants of FDI: market size, stable consuming expenses, innovation, and the quality of corporate governance. The main specific factors affecting the FDI influx in Central and Eastern Europe include natural resources, economic reforms, privatization, and access to the EU market. The negative factors in emerging economies may comprise bureaucracy, corruption, structural weaknesses, country risks, macroeconomic imbalances, disruption, and effects of the old economic system, weak capital markets, insufficient knowledge of the local markets, weak banking system, poor legal infrastructure, illegal activities and the influence of interest groups on privatization, and sometimes negative attitude towards foreign influence.

Veganzones-Varoudakis, Aysan and Baykal (2011) wrote about convergence in the region in 1992-2005 by control over corruption, the quality of bureaucracy, the law and order, the internal conflicts, and the ethnic tensions. The researchers also used a sample of developing economies. They concluded that the overall investment // GDP is positively affected by the quality of administration (control over corruption, quality of bureaucracy, law and order), democratic accountability (civil liberties, political rights, democratic accountability), and political stability (government stability, low internal conflict, less ethnic tensions).

Ganić and Hrnjic (2019) studied Central and Southeast European countries to identify the determinants of inward FDI. They found no signs evidencing the influence of the business regulatory environment (ease of doing business). Trade openness and low tax rates also do not guarantee attractiveness for FDI. Nevertheless, they suggest that a further increase in FDI may be stimulated by higher economic growth, political stability, integration with the EU, and reducing business regulation costs.

Lu, Kasimov, Karimov, and Abdullaev (2020) examined the CIS countries in 1998-2017 to prove that the FDI in the region positively depended on the availability of natural resources, economic freedom, access to the sea, larger market size, trade openness, enhanced telecommunications infrastructure, and low external debt. They recommended providing better economic freedom, lowering the tax burden and government spending, higher involvement in international trade, investment, and financial freedom.

Anagnostis (2011) summarized the usual effects of FDI: economic revival, GNP growth, export performance, enhanced competitive conditions, new technical and managerial knowledge, commercial transparency and openness, improved skills, structural changes in production, and stabilized balance of payments, a transition to the market economy.

Nevertheless, the correlation between FDI and economic growth was weak since the positive effects of FDI may be neutralized by production decrease in inefficient domestic firms. Several years ago, Apostolov (2006) used the Cobb-Douglas model to prove the effect of FDI on the economic development of Southeast Europe. Later Mehic, Silajdzic, and Babic-Hodovic (2013) established the positive FDI effect on the economic growth in Southeast Europe based on the trends in domestic investments and possible inverse causality.

Handjiski (2009) said that FDI stimulated the overall capital formation. Companies with FDI had better productivity than domestic enterprises. Todorov (2018) provided evidence that in Southeast Europe, FDI leads to higher economic concentration and thus skewed firm size distribution. 
According to Christie (2003), there was a complementarity instead of substitutability between trade and FDI in Central Europe. Yet, no significant link between them appeared in Southeast Europe. The reason was the prevalence of low-tech investments that did not create strong additional demand for intermediate goods from investor countries. Astrov and Havlik (2008) noted that a few years before 2006, Azerbaijan experienced current account deficits because of oil industry equipment imports financed with FDI. However, the growth of oil revenues resulted in a surplus later. A similar situation with FDI affecting imports of investment goods took place in many other Black Sea region countries.

\section{AIMS}

The article aims to study the FDI dynamics in the countries being a part of the Black Sea Economic Cooperation and the impact exerted by the investment climate on economic development.

\section{METHODS}

The scientific-theoretical and methodological basis of the research was formed by the following methods: publicity and system analysis, by classification, coefficient analysis, financial, economic and statistical analysis, and correlation and regression analysis.

The research used an analysis of the statistics provided by the United Nations Conference on Trade and Development (UNCTAD) and the International Monetary Fund (IMF) to assess trends in FDI in the BSEC countries. The data was analyzed in different periods of time by individual BSEC members, countries of origin of investments. Close attention was paid to both inward and outward FDI. Besides the absolute values, the share of the BSEC countries in the global FDI was discussed. Also, several ratios were used to assess the impact of FDI on economies:

- FDI/GDP - important to the economy in general;

- FDI/gross fixed capital formation (GFCF) - important to capital formation;

- inward FDI/imports - a direct negative effect on the trade balance;

- inward FDI/trade deficit - the ability to finance the trade deficit with less volatile capital inflows;

- income payments/FDI liabilities - the efficiency of investments for foreign investors;

- income payments minus reinvested earnings/FDI liabilities - a negative effect on the primary income balance.

Economic freedom indicators are used to assess the investment climate and its structural differences in the BSEC countries.

The time series of economic freedom and GDP growth are then analyzed using correlation analysis to check their relationship with inward FDI/GDP in each BSEC country in 1995-2018, although the analyzed period is shorter for some countries if the data for some years is not available. Correlation analysis is then used to find out the relationship between economic freedom sub-indices and inward FDI/GDP and GDP growth in all BSEC countries in 2011-2019. Regression analysis is used to create models for inward FDI/GDP and the GDP growth, which may both depend on the investment climate.

\section{RESULTS}

After the economic downturn in the 1990s, the share of the BSEC countries in the global inward FDI increased mainly in 2003-2008 (Table 1). As for Bulgaria and Romania, it was also a period when they were on their track to accession to the EU. The 2008-2009 crisis negatively affected investments in most BSEC countries. And the hybrid war was another negative circumstance that affected FDI both to Russia and Ukraine. Azerbaijan had the highest volatility in the inward FDI. 
Table 1. Trends in the BSEC countries' inward FDI, \%

Source: UNCTAD and authors' calculations

\begin{tabular}{|c|c|c|c|c|c|c|c|}
\hline Inward & $1992-1996$ & $1997-2001$ & $2002-2006$ & $2007-2011$ & 2012-2016 & 2017 & 2018 \\
\hline Albania & 0.3 & 0.5 & 1.2 & 4.6 & 5.3 & 1.1 & 1.3 \\
\hline Armenia & 0.1 & 0.6 & 1.2 & 3.6 & 1.8 & 0.2 & 0.3 \\
\hline Azerbaijan & 0.8 & 2.9 & 9.3 & -2.2 & 17.6 & 2.9 & 1.4 \\
\hline Bulgaria & 0.4 & 4.1 & 18.1 & 29.2 & 7.8 & 2.6 & 2.1 \\
\hline Georgia & $\begin{array}{l}\text { no data } \\
\text { available }\end{array}$ & 0.8 & 2.6 & 6.0 & 7.1 & 1.9 & 1.2 \\
\hline Greece & 5.2 & 4.3 & 9.4 & 10.5 & 11.3 & 3.6 & 4.3 \\
\hline Moldova & 0.1 & 0.4 & 0.8 & 2.2 & 1.1 & 0.2 & 0.2 \\
\hline Romania & 1.2 & 6.5 & 26.8 & 33.2 & 18.8 & 5.4 & 5.9 \\
\hline Russian Federation & 7.7 & 16.4 & 78.3 & 227.1 & 161.8 & 26.0 & 13.3 \\
\hline Serbia & $\begin{array}{l}\text { no data } \\
\text { available }\end{array}$ & $\begin{array}{l}\text { no data } \\
\text { available }\end{array}$ & $\begin{array}{l}\text { no data } \\
\text { available }\end{array}$ & 15.4 & 11.5 & 3.2 & 4.4 \\
\hline Turkey & 3.7 & 6.9 & 35.8 & 75.7 & 72.9 & 11.5 & 12.9 \\
\hline Ukraine & 1.3 & 3.2 & 17.2 & 39.3 & 19.6 & 2.6 & 2.4 \\
\hline BSEC, total & 21 & 47 & 201 & 445 & 336 & 61 & 50 \\
\hline World & 1.368 & 4.377 & 4.185 & 7.470 & 8.211 & 1.497 & 1.297 \\
\hline BSEC, share in the world & 1.5 & 1.1 & 4.8 & 6.0 & 4.1 & 4.1 & 3.8 \\
\hline
\end{tabular}

Few BSEC countries actively invest abroad (Table 2). Russia became an active source of FDI since 2003-2007, Azerbaijan - in 2003-2004 and since 2012, Greece - in 2006-2007 and Turkey - in 2012-2015.

Table 2. Trends in the BSEC countries' outward FDI, \%

Source: UNCTAD and authors' calculations.

\begin{tabular}{|c|c|c|c|c|c|c|c|}
\hline Outward & 1992-1996 & $1997-2001$ & $2002-2006$ & 2007-2011 & 2012-2016 & 2017 & 2018 \\
\hline Albania & $\begin{array}{l}\text { no data } \\
\text { available }\end{array}$ & $\begin{array}{l}\text { no data } \\
\text { available }\end{array}$ & $\begin{array}{l}\text { no data } \\
\text { available }\end{array}$ & 0.18 & 0.20 & 0.03 & 0.08 \\
\hline Armenia & $\begin{array}{l}\text { no data } \\
\text { available }\end{array}$ & $\begin{array}{l}\text { no data } \\
\text { available }\end{array}$ & 0.03 & 0.31 & 0.14 & 0.02 & -0.01 \\
\hline Azerbaijan & $\begin{array}{l}\text { no data } \\
\text { available }\end{array}$ & $\begin{array}{l}\text { no data } \\
\text { available }\end{array}$ & 4.39 & 1.93 & 11.75 & 2.56 & 1.76 \\
\hline Bulgaria & -0.04 & 0.03 & 0.33 & 1.66 & 1.38 & 0.36 & 0.39 \\
\hline Georgia & $\begin{array}{l}\text { no data } \\
\text { available }\end{array}$ & $\begin{array}{l}\text { no data } \\
\text { available }\end{array}$ & -0.09 & 0.48 & 1.54 & 0.27 & 0.34 \\
\hline Greece & 0.06 & 3.18 & 7.61 & 13.05 & 2.82 & 0.58 & 0.85 \\
\hline Moldova & $\begin{array}{l}\text { no data } \\
\text { available }\end{array}$ & 0.00 & 0.00 & 0.06 & 0.10 & 0.01 & 0.03 \\
\hline Romania & 0.01 & 0.00 & 0.68 & 0.38 & -0.20 & -0.10 & 0.01 \\
\hline Russian Federation & 4.40 & 12.24 & 73.28 & 224.79 & 217.35 & 34.15 & 36.44 \\
\hline Serbia & $\begin{array}{l}\text { no data } \\
\text { available }\end{array}$ & $\begin{array}{l}\text { no data } \\
\text { available }\end{array}$ & $\begin{array}{l}\text { no data } \\
\text { available }\end{array}$ & 0.97 & 1.80 & 0.20 & 0.42 \\
\hline Turkey & 0.35 & 2.63 & 3.39 & 10.01 & 22.03 & 2.63 & 3.61 \\
\hline Ukraine & $\begin{array}{l}\text { no data } \\
\text { available }\end{array}$ & 0.07 & 0.15 & 2.77 & 1.70 & 0.01 & -0.01 \\
\hline BSEC, total & 5 & 18 & 90 & 257 & 261 & 41 & 44 \\
\hline World & 1.474 & 4.068 & 4.117 & 7.906 & 7.186 & 1.425 & 1.014 \\
\hline BSEC, share in the world & 0.3 & 0.4 & 2.2 & 3.2 & 3.6 & 2.9 & 4.3 \\
\hline
\end{tabular}


Table 3 shows the FDI stocks and the key countries of origin and destination of FDI in the region. The Netherlands is an important investment hub in most BSEC countries. Switzerland, the United Kingdom, Germany, and Russia are also important sources of FDI. There are also investment links between neighboring or proximate countries (from Greece to Cyprus and Albania, from Azerbaijan to Georgia, from Serbia to Montenegro, Bosnia and Herzegovina, between Turkey and Azerbaijan, etc.). But sometimes, the data may differ in various sources.

Table 3. The main sources of FDI in the BSEC countries in 2018, \%

Source: Coordinated Direct Investment Survey (2020) and authors' calculations.

\begin{tabular}{|c|c|c|c|c|}
\hline Country & $\begin{array}{l}\text { Inward FDI, } \\
\text { stocks, \$ bln }\end{array}$ & Shares in the inward FDI, \% & $\begin{array}{l}\text { Outward FDI, } \\
\text { stocks, \$ bln }\end{array}$ & Shares in the outward FDI, \% \\
\hline Albania & 7.8 & $\begin{array}{l}\text { Switzerland }-19, \text { The Netherlands }-14 \text {, } \\
\text { Canada - 15, Greece }-12\end{array}$ & 0.56 & $\begin{array}{l}\text { Kosovo }-60 \\
\text { Italy }-29\end{array}$ \\
\hline Armenia & 5.1 & $\begin{array}{l}\text { Russian Federation - 34, United Kingdom } \\
-9\end{array}$ & 0.23 & $\begin{array}{l}\text { Georgia }-26 \\
\text { Latvia }-24\end{array}$ \\
\hline Azerbaijan & 30.7 & $\begin{array}{l}\text { United Kingdom - 22, Turkey - 19, } \\
\text { Norway - } 10\end{array}$ & 22.2 & $\begin{array}{l}\text { Turkey }-52 \\
\text { Georgia }-14\end{array}$ \\
\hline Bulgaria & 49.0 & The Netherlands - 18 , Austria - 9 & no data available & - \\
\hline Georgia & 18.3 & $\begin{array}{l}\text { Azerbaijan }-22 \text {, United Kingdom - 14, The } \\
\text { Netherlands }-10\end{array}$ & no data available & - \\
\hline Greece & 34.9 & $\begin{array}{l}\text { Germany }-23, \text { Luxembourg }-22, \\
\text { The Netherlands }-16, \text { Switzerland }-10\end{array}$ & 19.56 & $\begin{array}{l}\text { Cyprus - 26, } \\
\text { Hong Kong - 11, United States - 13, } \\
\text { The Netherlands - 10, Romania - } 9\end{array}$ \\
\hline Moldova & 3.7 & $\begin{array}{l}\text { Russian Federation - 23, The Netherlands - } \\
14 \text {, Cyprus }-8\end{array}$ & no data available & - \\
\hline Romania & 92.9 & $\begin{array}{l}\text { The Netherlands }-24 \text {, Germany - } 13 \text {, } \\
\text { Austria }-12 \text {, Italy }-9\end{array}$ & no data available & - \\
\hline $\begin{array}{l}\text { Russian } \\
\text { Federation }\end{array}$ & 409.7 & $\begin{array}{l}\text { Cyprus }-31 \text {, The Netherlands }-10 \text {, } \\
\text { Bahamas }-10\end{array}$ & 344.32 & $\begin{array}{l}\text { Cyprus - 51, } \\
\text { The Netherlands - } 12\end{array}$ \\
\hline Serbia & 39.8 & The Netherlands - 19, Austria - 11 & 3.82 & $\begin{array}{l}\text { Bosnia and Herzegovina }-26 \text {, } \\
\text { Montenegro }-21 \text {, Slovenia }-15\end{array}$ \\
\hline Turkey & 103.2 & $\begin{array}{l}\text { The Netherlands }-18, \text { Russian Federation } \\
-16\end{array}$ & 44.45 & $\begin{array}{l}\text { The Netherlands }-40 \text {, United } \\
\text { Kingdom }-9\end{array}$ \\
\hline Ukraine & 21.9 & $\begin{array}{l}\text { The Netherlands }-24 \text {, Switzerland }-12 \text {, } \\
\text { Germany }-10 \text {, United Kingdom }-9\end{array}$ & no data available & - \\
\hline
\end{tabular}

As for the importance of FDI in the BSEC economies (Table 4), Albania, Georgia, and Serbia largely depend on incoming FDI. Larger economies of Russia, Turkey, Ukraine, and Greece depend much less on them. But historically FDI accounted for 45\% of the country's GDP in 2003 in Azerbaijan, 28\% GDP in 2007 in Bulgaria; 98\% GFCF (gross fixed capital formation) in 2007 in Bulgaria, 85\% GFCF in 2003 in Azerbaijan, 71\% GFCF in 1998 in Armenia, 67\% GFCF in 2007 in Georgia, 64\% of GFCF in 2000 in Moldova, 40\% GFCF in 2005 in Ukraine, 38\% GFCF in 2004 in Romania, 19\% GFCF in 2007-2008 in Russia and 14\% GFCF in 2017 in Greece. This means that in some years, FDI will become a significant driver of the economy in most BSEC countries. In comparison to the GDP, Azerbaijan, Russia, and Georgia invest abroad relatively more. Other BSEC countries are much less involved in outward FDI.

Table 4. Importance of FDI for the BSEC economies

Source: UNCTAD (2020)

\begin{tabular}{|c|c|c|c|c|}
\hline Country & $\begin{array}{c}\text { Inward FDI, \% GDP in } \\
2018\end{array}$ & $\begin{array}{l}\text { Inward FDI, \% GFCF } \\
\text { in } 2017\end{array}$ & $\begin{array}{l}\text { Outward FDI, \% GDP } \\
\text { in } 2018\end{array}$ & $\begin{array}{c}\text { Outward FDI, \% GFCF } \\
\text { in } 2017\end{array}$ \\
\hline Albania & 8.46 & 34.8 & 0.54 & 0.79 \\
\hline Armenia & 2.02 & 12.5 & -0.09 & 1.11 \\
\hline Azerbaijan & 3.09 & 29.8 & 3.88 & 26.64 \\
\hline Bulgaria & 3.18 & 24.2 & 0.60 & 3.29 \\
\hline Georgia & 7.51 & 42.3 & 2.07 & 6.02 \\
\hline Greece & 1.95 & 13.8 & 0.39 & 2.22 \\
\hline Moldova & 2.38 & 9.2 & 0.32 & 0.77 \\
\hline Romania & 2.45 & 11.3 & 0.01 & -0.20 \\
\hline Russian Federation & 0.82 & 7.6 & 2.24 & 9.98 \\
\hline Serbia & 7.82 & 33.9 & 0.74 & 2.09 \\
\hline Turkey & 1.69 & 4.5 & 0.47 & 1.03 \\
\hline Ukraine & 1.89 & 14.5 & 0.00 & 0.04 \\
\hline
\end{tabular}


The research used the analysis of the statistical data provided by the United Nations Conference on Trade and Development (UNCTAD) and the International Monetary Fund (IMF) to assess the trends in FDI in the BSEC countries. The data was analyzed across the time, by individual BSEC members, countries of origin of investments. Careful consideration was given to both inward and outward FDI. Besides the absolute values, the discussion addressed the share of the BSEC countries in the global FDI. Also, several ratios were applied to assess the FDI effects for economies:

- FDI/GDP - important to the economy in general;

- FDI/gross fixed capital formation (GFCF) - important to capital formation;

- $\quad$ inward FDI/imports - a direct negative effect on the trade balance;

- inward FDI/trade deficit - the ability to finance the trade deficit with less volatile capital inflows;

- income payments/FDI liabilities - the efficiency of investments for foreign investors;

- income payments minus reinvested earnings/FDI liabilities - a negative effect on the primary income balance.

Economic freedom indicators are used to assess the investment climate and its structural differences in the BSEC countries.

Besides a positive effect on a country's GDP and capital formation, GDI may increase imports and investment income payments abroad (Table 5). In Azerbaijan, Albania, Georgia, and Serbia, FDIs generate a stronger additional demand for imports if compared to Greece, where their contribution to its imports is minor. On the other hand, FDI is a better way to offset trade deficits in those countries where imports exceed exports since the portfolio and other investments are usually more volatile. In Romania, FDI is the principal tool to cover the trade deficit. In several other BSEC countries, it covers about half of their trade deficits.

Table 5. The effect of FDI on imports and income payments, average values in 2010-2019, \%

Source: Authors' calculations based on the Balance of Payment Statistics (2020).

\begin{tabular}{|c|c|c|c|c|}
\hline Country & $\begin{array}{l}\text { Inward FDI / } \\
\text { imports }\end{array}$ & $\begin{array}{l}\text { Inward FDI / trade } \\
\text { deficit }\end{array}$ & $\begin{array}{l}\text { Income payments / } \\
\text { FDI liabilities }\end{array}$ & $\begin{array}{l}\text { Income payments minus } \\
\text { reinvested earnings / } \\
\text { FDI liabilities }\end{array}$ \\
\hline Albania & 17.9 & 48.3 & 3.7 & 1.8 \\
\hline Armenia & 6.9 & 19.7 & 4.2 & 1.8 \\
\hline Azerbaijan & 20.3 & no data available & no data available & no data available \\
\hline Bulgaria & 4.9 & no data available & 4.4 & 4.0 \\
\hline Georgia & 15.1 & 59.4 & 6.5 & 4.0 \\
\hline Greece & 3.3 & 37.8 & 0.1 & 2.5 \\
\hline Moldova & 5.2 & 11.0 & 5.5 & 4.0 \\
\hline Romania & 5.6 & 83.2 & 4.9 & 5.1 \\
\hline Russian Federation & 9.6 & no data available & 12.3 & 8.4 \\
\hline Serbia & 11.6 & 56.1 & 5.5 & 2.8 \\
\hline Turkey & 5.4 & 45.1 & 1.8 & 1.6 \\
\hline Ukraine & 5.7 & 46.7 & 5.7 & 5.4 \\
\hline
\end{tabular}

The highest FDI efficiency for investors is in Russia (12.3\%). But considering the structure of FDI by countries of origin, one can assume that a lot of FDI in Russia is actually of Russian origin incoming through foreign intermediary companies. And therefore, it can be a form of a capital flight which also may take place in some other countries. The lowest ratio of income payments to FDI liabilities (0.1\%) is seen in Greece because of the negative values during the period of a severe debt crisis. However, the indicator improved in 2014, and in 2019 it was 3.2\%. Turkey also has a relatively small ratio with a flat trend. But since some of the income is reinvested, a more significant indicator for a recipient country would be income payments minus reinvested earnings/FDI liabilities. Russia, Ukraine, and Romania have the largest ratios for income payments that are not reinvested.

Georgia, Bulgaria, Romania, Armenia, and Azerbaijan have a relatively better score by economic freedom index (out of 180 countries), while Ukraine and Greece lag behind. But rankings differ by particular indicators and subindices (Tables 6-7). All the 12 BSEC countries have better than average trade freedom and lower than average 
tariffs, which may favor creating international production chains. Almost all the countries have better than the average situation by tax burden, fiscal health, financial freedom, property rights, and inflation. Most countries perform relatively better through business freedom, public debt, judicial effectiveness, investment freedom, and GDP growth. Only about half of the countries have better than the average score by monetary freedom, government spending, labor freedom, and government integrity. The latter indicator, which is closely related to the absence of corruption and excessive regulations, is, apparently, a weakness in most cases.

Table 6. Investment climate indicators of the BSEC countries

Source: The Heritage Foundation (2020) and authors' calculations.

\begin{tabular}{|c|c|c|c|c|c|c|c|c|}
\hline Country & $\begin{array}{l}\text { Economic } \\
\text { freedom, } \\
\text { world rank }\end{array}$ & $\begin{array}{c}\text { GDP } \\
\text { growth } \\
\text { rate (\%) }\end{array}$ & $\begin{array}{c}\text { Inflation } \\
(\%)\end{array}$ & $\begin{array}{c}\text { Public } \\
\text { debt (\% of } \\
\text { GDP) }\end{array}$ & $\begin{array}{c}\text { Tariff rate } \\
(\%)\end{array}$ & $\begin{array}{c}\text { Income } \\
\text { tax rate } \\
(\%)\end{array}$ & $\begin{array}{c}\text { Corporate } \\
\text { tax rate } \\
(\%)\end{array}$ & $\begin{array}{c}\text { Tax } \\
\text { burden (\% } \\
\text { of GDP) }\end{array}$ \\
\hline Albania & 57 & 4.162 & 2.0 & 68.6 & 0.8 & 23 & 15 & 25.7 \\
\hline Armenia & 34 & 5.028 & 2.5 & 48.5 & 2.2 & 26 & 20 & 20.8 \\
\hline Azerbaijan & 44 & 1.352 & 2.3 & 19.4 & 5.2 & 25 & 20 & 13.3 \\
\hline Bulgaria & 36 & 3.2 & 2.6 & 20.5 & 1.8 & 10 & 10 & 27.7 \\
\hline Georgia & 12 & 4.708 & 2.6 & 44.5 & 0.7 & 20 & 15 & 25.7 \\
\hline Greece & 100 & 2.098 & 0.8 & 183.3 & 1.8 & 42 & 28 & 39.4 \\
\hline Moldova & 87 & 4 & 3.1 & 27.1 & 3.5 & 12 & 12 & 33.2 \\
\hline Romania & 38 & 4.127 & 4.6 & 36.6 & 1.8 & 10 & 16 & 24.7 \\
\hline Russian Federation & 94 & 2.334 & 2.9 & 14.0 & 3.6 & 13 & 20 & 24.2 \\
\hline Serbia & 65 & 4.354 & 2.0 & 54.3 & 6 & 10 & 15 & 36.1 \\
\hline Turkey & 71 & 2.567 & 16.3 & 29.1 & 3.5 & 35 & 22 & 24.9 \\
\hline Ukraine & 134 & 3.291 & 10.9 & 63.9 & 1.9 & 20 & 18 & 34.2 \\
\hline Global average & - & 3.1 & $4.8^{*}$ & 56.9 & 5.9 & 28.1 & 23.7 & 21.7 \\
\hline
\end{tabular}

Note: * - without Venezuela.

The investment climate trends should also be considered. For example, in 2020, the overall economic freedom score improved by 8.9 in Russia, by 8.3 in Azerbaijan, by 8 in Ukraine, by 6 in Serbia, and by 5.9 in Greece in comparison to 2015. Only minor improvement took place in Turkey and Albania (by 1.2).

Table 7. The economic freedom subindices of the BSEC countries, score

Source: The Heritage Foundation (2020) and authors' calculations.

\begin{tabular}{|c|c|c|c|c|c|c|c|c|c|c|c|c|}
\hline Country & 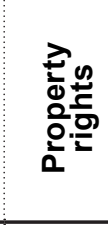 & 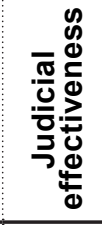 & 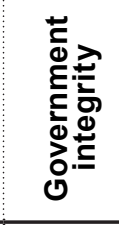 & 들 & 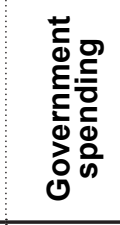 & 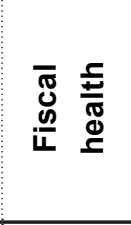 & 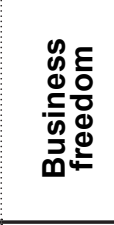 & 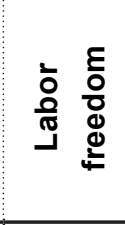 & 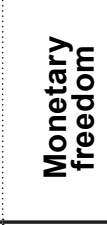 & 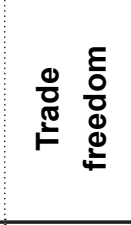 & 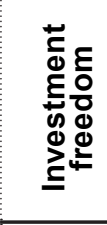 & 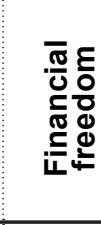 \\
\hline Albania & 57.1 & 33 & 38.8 & 85.9 & 74.6 & 86.3 & 65.7 & 52.1 & 81.2 & 88.4 & 70 & 70 \\
\hline Armenia & 60.7 & 54.1 & 43.4 & 84.9 & 80.6 & 68.8 & 81 & 72.5 & 76 & 80.6 & 75 & 70 \\
\hline Azerbaijan & 67.1 & 53.9 & 38.7 & 88 & 63 & 99.2 & 80.8 & 66.2 & 69.8 & 74.6 & 70 & 60 \\
\hline Bulgaria & 64.2 & 45.4 & 44.2 & 90.3 & 66.1 & 99.2 & 62.6 & 68.1 & 85.7 & 86.4 & 70 & 60 \\
\hline Georgia & 68.6 & 57.9 & 64.8 & 87.1 & 73.6 & 94.4 & 85.3 & 76.3 & 78.3 & 88.6 & 80 & 70 \\
\hline Greece & 57 & 48.6 & 51.2 & 59 & 31.5 & 80 & 73.7 & 52 & 79.4 & 81.4 & 55 & 50 \\
\hline Moldova & 60.5 & 31.7 & 37.2 & 86.1 & 71.6 & 96.2 & 68.1 & 37 & 72 & 78 & 55 & 50 \\
\hline Romania & 72.5 & 56.1 & 55.1 & 90.3 & 70.4 & 85.6 & 58.6 & 63 & 78.1 & 86.4 & 70 & 50 \\
\hline $\begin{array}{l}\text { Russian } \\
\text { Federation }\end{array}$ & 56.8 & 44.4 & 41.3 & 88.5 & 63.8 & 98.7 & 80.2 & 52.1 & 68.2 & 77.8 & 30 & 30 \\
\hline Serbia & 55.4 & 46.8 & 44 & 83.7 & 49.7 & 94.1 & 72.6 & 66.9 & 80.7 & 78 & 70 & 50 \\
\hline Turkey & 57.4 & 53.7 & 44.6 & 76.7 & 64.1 & 86.1 & 67 & 49.2 & 66.1 & 78 & 70 & 60 \\
\hline Ukraine & 47.5 & 42.2 & 37.9 & 81.1 & 47.2 & 83.9 & 61.3 & 48.3 & 63 & 81.2 & 35 & 30 \\
\hline $\begin{array}{l}\text { Global } \\
\text { average }\end{array}$ & 56.6 & 45.1 & 43.8 & 77.3 & 66.0 & 69.1 & 63.3 & 59.4 & 74.6 & 73.8 & 57.2 & 49.0 \\
\hline
\end{tabular}


The correlation analysis in Table 8 shows that FDI depends on the recipient country's GDP in Georgia, Russia, Romania, Ukraine, Bulgaria, and possibly Moldova, where the significance of the correlation is marginal. There is no significant correlation with the world GDP growth and the EU-28 GDP growth, which does not prove the effect of GDP growth in all potential countries of origin of FDI. There is a positive effect of economic freedom in the recipient country in the case of Albania, Ukraine, and Georgia. And there is a negative correlation between economic freedom and inward FDI in Greece. Therefore, the analysis of time series by countries shows that economic growth and economic freedom in a recipient economy attract FDI only in some cases. Nevertheless, the overall correlations between inward FDI/GDP and the recipient country's GDP growth were 0.51 in 2018 and between inward FDI/GDP and economic freedom - 0.41 . This means that despite short term positive effects of accelerating economic growth and improvement of economic freedom in a country are not guaranteed, investments flow relatively more to those BSEC countries which perform better by this indicator, at least recently.

Table 8. Correlations between inward FDI/GDP (\%) and GDP growth (\%) and economic freedom (score) in 1995-2018

Source: Authors' calculations based on UNCTAD (2020) and the Heritage Foundation (2020).

\begin{tabular}{|c|c|c|c|c|c|c|}
\hline Country & $\begin{array}{c}\text { Domestic } \\
\text { GDP }_{+}\end{array}$ & $\begin{array}{c}\text { Domestic } \\
\text { GDPt }_{-1}\end{array}$ & World GDP $_{t}$ & $\begin{array}{c}\text { EU28 } \\
\text { DP }_{+}\end{array}$ & $\begin{array}{l}\text { Economic } \\
\text { freedom }_{t}\end{array}$ & $\begin{array}{l}\text { Economic } \\
\text { freedomt }_{-1}\end{array}$ \\
\hline Albania & -0.16 & -0.21 & -0.20 & -0.37 & 0.91 & 0.88 \\
\hline Armenia & 0.14 & 0.28 & 0.00 & -0.08 & 0.05 & -0.21 \\
\hline Azerbaijan & 0.04 & -0.16 & 0.12 & 0.11 & -0.38 & -0.37 \\
\hline Bulgaria & 0.37 & 0.44 & 0.32 & 0.16 & 0.13 & 0.07 \\
\hline Georgia & 0.60 & 0.54 & 0.29 & 0.19 & 0.47 & 0.38 \\
\hline Greece & 0.16 & -0.12 & -0.02 & 0.03 & -0.36 & -0.66 \\
\hline Moldova & 0.39 & 0.15 & 0.22 & 0.13 & 0.23 & 0.36 \\
\hline Romania & 0.46 & 0.33 & 0.34 & 0.21 & -0.14 & -0.33 \\
\hline Russian Federation & 0.52 & 0.48 & 0.13 & -0.08 & -0.10 & -0.03 \\
\hline Serbia & 0.15 & 0.12 & -0.14 & 0.05 & 0.12 & -0.01 \\
\hline Turkey & 0.04 & 0.36 & 0.12 & -0.02 & 0.08 & -0.12 \\
\hline Ukraine & 0.43 & 0.49 & 0.17 & -0.12 & 0.58 & 0.72 \\
\hline
\end{tabular}

Table 9 shows the effect of economic freedom on incoming FDI and GDP growth (significant correlations are more than 0.2) in all the BSEC countries. In most cases, the subindices influence them both with no and lyear lag. Contrary to common sense, property rights and trade freedom do not strongly influence inward FDI. The overall economic freedom and low tax burden are the most significant factors of inward FDI to the BSEC countries. When it comes to the effect on the GDP growth, labor freedom and monetary growth are not significant factors. Instead, overall economic freedom and better control over government spending are the most crucial for stimulating economic growth. 
Table 9. Correlations between inward FDI/GDP (\%), GDP growth (\%) and economic freedom subindices (score)

Source: Authors' calculations based on UNCTAD (2020), World Economic Outlook (2020) and the Heritage Foundation (2020)

\begin{tabular}{|c|c|c|c|c|}
\hline Indicators & $\begin{array}{c}\text { Inward FDI/GDP, } \\
2011-2018\end{array}$ & $\begin{array}{c}\text { Inward FDI/ } \\
\text { GDP }_{\mathrm{t}+1}, \\
2011-2018\end{array}$ & $\begin{array}{l}\text { GDP growth } \\
\text { rate, annual, } \\
2011-2019\end{array}$ & $\begin{array}{c}\text { GDP growth rate, } \\
\text { annual }{ }^{\prime}, \\
2011-2019\end{array}$ \\
\hline Overall economic freedom score & 0.42 & 0.44 & 0.42 & 0.45 \\
\hline Property rights & -0.03 & -0.08 & 0.31 & 0.22 \\
\hline Government integrity & 0.22 & 0.15 & 0.28 & 0.36 \\
\hline Tax burden & 0.43 & 0.45 & 0.28 & 0.27 \\
\hline Government spending & 0.30 & 0.33 & 0.47 & 0.42 \\
\hline Business freedom & 0.30 & 0.36 & 0.11 & 0.21 \\
\hline Labor freedom & 0.37 & 0.41 & 0.13 & 0.14 \\
\hline Monetary freedom & 0.34 & 0.38 & 0.04 & 0.08 \\
\hline Trade freedom & 0.19 & 0.16 & 0.16 & 0.20 \\
\hline Investment freedom & 0.30 & 0.31 & 0.33 & 0.41 \\
\hline Financial freedom & 0.37 & 0.36 & 0.28 & 0.33 \\
\hline
\end{tabular}

The final regression model $\left(R^{2}=0.28\right.$, the number of cases -96 , all the regression coefficients are significant $)$ for inward FDI/GDP (IFDI) includes overall economic freedom (EF) index score and low tax burden (TB) score:

$I F D I=-13.65+0.114 E F+0.128 T B$.

The final regression model $\left(\mathrm{R}^{2}=0.31\right.$, the number of cases -106 , all the regression coefficients are significant $)$ for inward GDP growth (GDP) includes property rights (PR) and control over the government spending (GS):

$G D P=-5.75+0.078 P R+0.091 G S$.

This means that various initiatives to improve economic freedom and taxation decrease can attract FDI to the BSEC countries. Notably, improvement control over government spending and protecting property rights is crucial for economic growth.

\section{CONCLUSIONS}

The BSEC countries became quite attractive for FDI at the beginning of the 2000s and now receive about $4 \%$ of world FDI. All the BSEC countries are a net recipient of FDI, but some also invest abroad actively (Russia, Azerbaijan - by the absolute values and relatively their GDP; Turkey and Greece - by the absolute values only). The Netherlands, Switzerland, United Kingdom, Germany, and Russia are the main investors in the region. Sometimes, investments are related to capital flight and neighboring countries.

Albania, Georgia, and Serbia mostly depend on incoming FDI, while larger economies are more self-sufficient in investments. Occasionally, significant inflows of FDI occurred in almost each BSEC country, which made a crucial contribution to their capital formation. FDI also contributed to an increase in imports, especially in Azerbaijan, Albania, Georgia, and Serbia. On the other hand, FDI also helped to make trade deficits less vulnerable to sudden stops of other capital inflows. The BSEC countries vary a lot by FDI efficiency for investors and by the earnings reinvestment ratio. For example, in Russia, FDI generates outflows of income paid (less reinvested earnings) to at least nominally foreign investors, which is equivalent to almost $4 \%$ of its FDI liabilities.

Georgia, Bulgaria, Romania, Armenia, and Azerbaijan are the best performing countries by economic freedom 
index in the region. And despite some drawbacks, Russia, Azerbaijan, Ukraine, Serbia, and Greece had the fastest pace of improvements by economic freedom. Most BSEC countries usually outperform average countries worldwide by trade freedom, low tax burden, fiscal health, financial freedom, property rights, and low inflation. But this group of countries is quite diverse by particular indicators. Corruption and excessive regulations is often a drawback of the investment climate.

Accelerating economic growth and improvement of economic freedom do not guarantee an increase in FDI inflows in each particular case. But the overall economic freedom and low tax burden are the most significant factors of inward FDI to the BSEC countries. Improving the overall economic freedom, protecting property rights, and better control over government spending are the most crucial for stimulating economic growth. Trade freedom seems to be a less important factor both for attracting FDI and economic growth.

\section{AUTHORS CONTRIBUTIONS}

Conceptualization: Evangelos Siskos, Konstantia Darvidou.

Data curation: Evangelos Siskos, Konstantia Darvidou.

Formal Analysis: Konstantia Darvidou.

Investigation: Evangelos Siskos, Konstantia Darvidou.

Methodology: Evangelos Siskos, Konstantia Darvidou.

Resources: Evangelos Siskos, Konstantia Darvidou.

Supervision: Evangelos Siskos.

Visualization: Evangelos Siskos, Konstantia Darvidou.

Writing - original draft: Evangelos Siskos, Konstantia Darvidou.

\section{REFERENCES}

1. Anagnostis, K. (2011). FDI and Impacts of Country Risk - Factors Affecting the Influx of FDI in Emerging Economies. Scientific Bulletin Economic Sciences, 10(2), 89-97. Retrieved from http://economic.upit.ro/repec/pdf/2011_2_8.pdf

2. Apostolov, M. (2016). Cobb-Douglas production function on FDI in Southeast Europe. Journal of Economic Structures, 5(1), 1-28. https:// doi.org/10.1186/s40008-016-0043-x

3. Astrov, V., \& Havlik, P. (2008). Economic Developments in the Wider Black Sea Region (Research Reports No. 349 ) (37 p.). Wien: The Vienna Institute for International Economic Studies. Retrieved from https://wiiw.ac.at/economic-developments-in-the-wider-black-searegion-dlp-458.pdf

4. Botrić, V., \& Škuflić, L. (2006). Main Determinants of Foreign Direct Investment in the Southeast European Countries. Transition Studies Review, 13(2), 359-377. https://doi.org/10.1007/s11300-006-0110-3

5. Christie, E. (2003). Foreign Direct Investment in Southeast Europe (Working Papers No. 24) (31 p.). Wien: The Vienna Institute for International Economic Studies. Retrieved from https://wiiw.ac.at/foreign-direct-investment-in-southeast-europe-dlp-523.pdf

6. Ganić, M., \& Hrnjic, M. (2019). Does a country's business regulatory environment affect its attractiveness to FDI? Empirical evidence from Central and Southeast European countries. Eastern Journal of European Studies, 10(2), 89-105. Retrieved from http://ejes.uaic.ro/articles/ EJES2019_1002_GAN.pdf

7. Glinavos, I. (2005). Foreign Direct Investment in the Black Sea Area. Germany: University Library of Munich. Retrieved from https://econwpa.ub.uni-muenchen.de/econ-wp/dev/papers/0506/0506007.pdf

8. Handjiski, B. (2009). Investment Matters: The Role and Patterns of Investment in Southeast Europe (The World Bank Working Paper No. 159). Retrieved from https://openknowledge.worldbank.org/bitstream/handle/10986/5920/473990PUB0Inve101OFFICIAL0USE0ON LY1.pdf? sequence $=1$

9. International Monetary Fund (2020). Balance of Payments and International Investment Position Statistics. Retrieved from https://data.imf. org/?sk=7A51304B-6426-40C0-83DD-CA473CA1FD52

10. International Monetary Fund (2020). Coordinated Direct Investment Survey. Retrieved from https://data.imf.org/?sk=40313609-F03748C1-84B1-E1F1CE54D6D5

11. International Monetary Fund (2020). World Economic Outlook Database. Retrieved from https://www.imf.org/external/pubs/ft/ weo/2020/01/weodata/download.aspx

12. Lu, W., Kasimov, I., Karimov, I., \& Abdullaev, Y. (2020). Foreign Direct Investment, Natural Resources, Economic Freedom, and Sea-Access: Evidence from the Commonwealth of Independent States. Sustainability, 12(8), 1-18. https://doi.org/10.3390/su12083135

13. Mehic, E., Silajdzic, S., \& Babic-Hodovic, V. (2013). The Impact of FDI on Economic Growth: Some Evidence from Southeast Europe. Emerging Markets Finance and Trade, 49(S1), 5-20. https://doi.org/10.2753/REE1540-496X4901S101

14. Papazoglou, Ch., \& Liargovas, P. (1997). An Assessment of Foreign Direct Investment Towards the BSEC Transition Economies. Economia Internazionale / International Economics, 50(3), 475-487. 
15. Salavrakos, I.-D. (2006). Explaining different FDI inflows in Eastern European countries with reference to economic history. Global Business and Economics Review, 8(1/2), 60-86. https://dx.doi.org/10.1504/GBER.2006.008777

16. Stoian, C., \& Filippaios, F. (2008). Dunning's eclectic paradigm: A holistic, yet context specific framework for analysing the determinants of outward FDI: Evidence from international Greek investments. International Business Review, 17(3), 349-367. https://doi.org/10.1016/j. ibusrev.2007.12.005

17. The Heritage Foundation (2020). Index of Economic Freedom. Retrieved from https://www.heritage.org/index/explore

18. Todorov, A. (2018). Foreign Investment and Aggregate Concentration - Evidence from Southeast Europe (Bulgarian Economic Paper No. bep-13-2018). Retrieved from https://www.uni-sofia.bg/index.php/eng/content/download/206594/1400938/file/BEP-2018-13.pdf

19. Troyan, I. (2012). Integration compatibility of BSEC member states. Business Inform, 9, 68-73. Retrieved from http://www.businessinform.net/annotated-catalogue/?year=2012\&abstract=2012_09_0\&lang=en\&stqa=9

20. UNCTAD (2020). Data Center. Retrieved from https://unctadstat.unctad.org/wds/ReportFolders/reportFolders.aspx?sCS_ ChosenLang=en

21. Veganzones-Varoudakis, M.-A., Aysan, A., \& Baykal, O. (2011). The Effects of Convergence in Governance on Capital Accumulation in the Black Sea Economic Cooperation Countries (Working Paper No. 611). Economic Research Forum. Retrieved from https://erf.org.eg/app/ uploads/2014/08/611.pdf

22. Vlahinic-Dizdarevic, N., \& Blažic, H. (2006). FDI determinants in Southeast European Countries with Special reference to Tax Incentives. Economic Studies journal, 3, 34-57. Retrieved from https://ideas.repec.org/a/bas/econst/y2006i3p34-57.html 